\title{
Biotechnology and naturalness in the genomics era: plotting a timetable for the biotechnology debate
}

\author{
Hub Zwart
}

Accepted: 14 May 2009/Published online: 26 June 2009

(C) The Author(s) 2009. This article is published with open access at Springerlink.com

\begin{abstract}
Debates on the role of biotechnology in food production are beset with notorious ambiguities. This already applies to the term "biotechnology" itself. Does it refer to the use and modification of living organisms in general, or rather to a specific set of technologies developed quite recently in the form of bioengineering and genetic modification? No less ambiguous are discussions concerning the question to what extent biotechnology must be regarded as "unnatural." In this article it will be argued that, in order to disentangle some of the ambiguities involved, we have to broaden the temporal horizon of the debate. Ideas about biotechniques and naturalness have evolved in various socio-historical contexts and their historical origins will determine to a considerable extent their actual meaning and use in contemporary deliberations. For this purpose, a comprehensive timetable is developed, beginning with the Neolithic revolution $\sim 10,000$ years ago (resulting in the emergence of agriculture and the Common Human Pattern) up to the biotech revolution as it has evolved from the 1970s onwards-sometimes referred to as a second "Genesis." The concept of nature that emerged in the context of the "Common Human Pattern" differs considerably from traditional philosophical concepts of nature (such as coined by Aristotle), as well as from the scientific view of nature conveyed by the contemporary life sciences. A clarification of these different historical backdrops will allow us to understand and elucidate the conceptual ambiguities that are at work in contemporary debates on biotechnology and the place of human beings in nature.
\end{abstract}

Keywords Naturalness · Biotechnology · Food ethics · Genomics · Neolithic revolution · Genetic engineering 
Food is contested like never before (Lien \& Anthony 2007, p. 413).

\section{Introduction}

Debates on the role of biotechnology in food production are beset with a number of pernicious ambiguities. One of them concerns the concept of "biotechnology" itself. Some authors treat it as a rather general term, referring to any technological application using living organisms. Taken in this sense, biotechnology is about 10,000 years old and its history more or less reflects the history of mankind during the past ten millennia or so. For others, it refers to a specific set of techniques that emerged during the so-called biotech revolution. It the latter case, biotechnology is synonymous (more or less) with genetic engineering through gene transfer. ${ }^{1}$

Both definitions have normative consequences. By choosing one rather than the other, we are already positioning ourselves in the debate. Those who start from the more general definition are likely to argue (and rightly so, it seems) that the current biotech revolution is merely another chapter in a long history of biotechnological modifications, one that virtually coincides with human history itself. We have been modifying nature since time immemorial. Biotechnology is part of the human condition and modifying animals, plants, and environments has become a "natural" thing for us to do. Genetic engineering merely means that organisms can now be changed with greater levels of precision (see for instance Wolpert 1993; Miller 2007). Those, however, who opt for the stricter definition tend to claim (and again, apparently for good reasons) that the biotech revolution as it has been evolving since the 1970s is an event of tremendous proportions, without precedent in history, a dramatic leap into a post-natural future (see for instance Rifkin 1998/1999; Bruce and Bruce 1999). From this perspective, biotechnology tends to be regarded as "unnatural." Both accounts seem viable, to some extent, but are difficult to combine into one single coherent and comprehensive view. Reiss and Straughan (1996) address the issue by focusing on scale and pace. Whereas "traditional" biotechnology has genetically altered only a limited number of species and at a relatively slow pace, genetic engineering is now characterized by its "suddenness" (p. 2), having the potential of affecting a considerable number of species. Yet, as increase in pace and scale seems a "natural" feature of techno-cultural developments as such, the question whether we are really facing something unprecedented remains as yet undecided. According to Miller (2007), setting genetic engineering apart as unique merely serves political purposes, in the sense that (on conceptually questionable grounds) biotech products can subsequently become the target of excessive and "discriminatory" forms of surveillance.

\footnotetext{
${ }^{1}$ See for instance the Wikipedia article on biotechnology. Although the authors are aware that biotechnology is often used to refer more specifically to genetic engineering technologies of present times, they nonetheless emphasize that, in their view, the term encompasses "a wider range and history of procedures for modifying biological organisms according to the needs of humanity, going back to the initial modifications of native plants into improved food crops through artificial selection and hybridization." http://en.wikipedia.org/wiki/Biotechnology.
} 
Situated at the other pole of the discursive battle-field, as the conceptual counterpart of (bio)technology as it were, we find a second ambiguity that torments the debate, namely the ambiguity concerning concepts such as "nature" or "naturalness." Although some authors-notably analytically inclined professional bioethicists - try to convince us that such concepts should be avoided or even erased altogether, they continue to resurge, both in scholarly discourse and in public debate, either directly or in the disguise of associated concepts such as "integrity" (Verhoog 2003). Thus, they seem inevitable articulations of important intuitions. As such, they constitute a conceptual challenge that we will have to address (Zwart 1994, 1998). In other words, although conceptual analysis is important, the problems involved in concepts such as "biotechnology" or "naturalness" are not of a purely semantic type.

One way to come to terms with them is to approach them from a historical angle, which is the route that will be taken in this paper. I will opt for an in-depth inquiry into the tensions that give rise to the semantic difficulties "at the surface," as symptoms of more "chronic" afflictions. For practical purposes, I will use the term "biotechnology" to refer to modifications of living organisms in general, while the short-hand version "biotech" will refer to genetic engineering-to biotechnology stricto sensu - but this can only be a provisional "solution," concealing rather than solving underlying tensions. Both definitions represent competing and incompatible views on the role of biotechnology in human life in general and food production in particular. I will argue that, in order to recognize the strengths and weaknesses of both accounts, the newness of the biotech revolution (as a transformation of epochal dimensions) can be best understood when it is seen against the backdrop of a long history of biotechnological transformations.

The question then becomes which particular events, which moments in time could serve as a backdrop, as historical markers, that will allow us to deepen our understanding of the significance of the current biotech revolution? A number of candidate events present themselves. Among continental philosophers it is established practice to start with the birth of philosophy, around 500BC, and the writings of Plato and Aristotle. Ancient Greek thinking often allows us to discern more precisely, and in a comparative manner so to speak, the newness or uniqueness of our contemporary practices and reflections, also concerning food (Zwart 2000). On the other hand, although ancient Greek philosophy, as a key component of the "first" scientific revolution that occurred 2,500 years ago in Ancient Greece, did have a tremendous impact on mathematics, philosophy, politics, and ethics, it hardly affected agriculture or "biotechnology" directly. For reasons that will be explained more fully below, authors such as Plato and Aristotle did hardly concern themselves with concrete interactions with nature in rural agricultural environments.

Another dramatic turning point has been the Industrial Revolution that included the "industrialization" of food production, based on a "scientification" of our understanding of life, made possible by the work of scientists such as Lavoisier (chemistry of fermentation), Pasteur (microbiology of fermentation), and Mendel (genetics of selective breeding). Although hugely important in themselves, to allow these events to suffice as points of orientation would still reflect a certain level of short-sightedness. In order to really understand what is happening today, we have to 
broaden our perspective, our temporal horizon. The primary point of reference should be the Neolithic revolution, the emergence of agriculture (or, rather, of agricultures, that is: of agricultural societies) that took place $\sim 10,000$ years ago, as the origin of what came to be known as the "Common Human Pattern" (CHP), a way of life that established itself throughout the human world, only to be disrupted by modern industrialization (Romein and Romein-Verschoor 1954). The Dutch historians Jan and Annie Romein defined the CHP as a stage in human history characterized by a wide-spread and relatively stable agricultural life-style, practiced in small-scale villages that were virtually self-supportive. Both events, the Neolithic revolution and the Industrial one, put the CHP between parentheses as it were, as the A and the $\Omega$ of a grand, but now closed, epoch.

If we analyze the course of events from such a perspective, moreover, it is important to emphasize that, until quite recently, agriculture, philosophy, and science constituted separate "streams" in history. Historically speaking, both a science of agriculture and a philosophy (or ethics) of agriculture are quite recent phenomena. The CHP, as a result of the Neolithic revolution, was based on practical, every-day knowledge forms that were transmitted through oral communication and on-site learning. Agriculture as a science-based practice is a fairly recent phenomenon. The scientific elucidation of some of the core techniques that brought about the Neolithic revolution, such as crop cultivation through selection and hybridization, or fermentation in the context of food preservation, took place rather recently, while ethical and/or philosophical reflections on food production and consumption have until quite recently remained neglected areas of discourse.

Nowadays, this has dramatically changed of course. In the context of the current biotech revolution, bioscience, biotechnology, and bioethics have become intimately connected and have dramatically affected agricultural practices. Bioscience and biotechnology have almost completely merged into a field that might be referred to as the biotechnosciences, while food production in general, and biotech in particular, have become key issues on the agenda of contemporary philosophy, as is exemplified by the very existence of this journal. One could say that it took philosophers 25 centuries to acknowledge the pivotal importance of food production for human existence. But now, this has become inevitable. In order to come to terms with the present, to "capture it in thoughts," as Hegel phrased it, contemporary philosophy can no longer afford to leave food production out of the picture. Indeed, the merger of bioscience and biotechnology has led to a dramatic revaluation of all values, to use the Nietzschean phrase. As will be discussed more thoroughly below, what was regarded as "natural" (and therefore "legitimate") for millennia, in the context of the CHP, is no longer seen as such from a bio-scientific perspective.

The point of departure of this article is the conviction that the way in which we frame and address issues of biotechnology and naturalness will be determined to a considerable extent by the way we see ourselves against the backdrop of our past. Those who regard the CHP as the natural and truly human way of life are bound to frame the biotechnology debate differently than those who opt for a more scienceoriented or "biologistic" view. In final instance, the biotechnology debate is not about definitions, but about the question how to assess an on-going transformation of human life of dramatic proportions, the scope of which can only become clear 
against the backdrop of a concise account of human history as such. And this is precisely what this article sets out to do. As a kind of basic scheme or temporal horizon, the following timetable will serve as point of departure:

\begin{tabular}{|c|c|c|c|c|}
\hline Years ago & Revolutions & Subsistence & Philosophy & Knowledge \\
\hline$\sim 250,000$ & $\begin{array}{l}\text { Emergence of Homo } \\
\text { sapiens }\end{array}$ & \multirow{2}{*}{$\begin{array}{l}\text { Hunting and } \\
\text { gathering; Promethean } \\
\text { revolution } \\
\text { (pyrotechnology) }\end{array}$} & \multirow[t]{4}{*}{$\begin{array}{c}\text { Mythological } \\
\text { cosmologies }\end{array}$} & \multirow[t]{2}{*}{$\begin{array}{l}\text { Primeval } \\
\text { knowledge }\end{array}$} \\
\hline$\sim 100,000$ & $\begin{array}{l}\text { Emergence of modern } \\
\text { humans / migration } \\
\text { "Out of Africa" }\end{array}$ & & & \\
\hline$\sim 10,000$ & $\begin{array}{l}\text { Neolithic } \\
\text { revolution: } \\
\text { "biotechnological" } \\
\text { revolution }\end{array}$ & Emergence of agriculture & & \multirow[t]{2}{*}{$\begin{array}{l}\text { Informal } \\
\text { practical knowledge }\end{array}$} \\
\hline$\sim 5,000$ & Urban revolution & $\begin{array}{l}\text { Agriculture reaches } \\
\text { what is now Western } \\
\text { Europe }\end{array}$ & & \\
\hline$\sim 2.500$ & $\begin{array}{l}\text { Beginnings of empire } \\
\text { building }\end{array}$ & & \begin{tabular}{|l|} 
Birth of \\
philosophical \\
cosmologies
\end{tabular} & $\begin{array}{l}\text { "First" } \\
\text { scientific revolution }\end{array}$ \\
\hline$\sim 1.500$ & Christianization & Monasticism & $\begin{array}{c}\text { Metaphysical } \\
\text { cosmologies }\end{array}$ & \\
\hline$\sim 500$ & Modernity & $\begin{array}{l}\text { Colonization: } \\
\text { migration of farmers, } \\
\text { animals and crops }\end{array}$ & Rationalism & $\begin{array}{l}\text { "Second" } \\
\text { scientific revolution }\end{array}$ \\
\hline$\sim 250$ & "Industrial" revolution & $\begin{array}{l}\text { "Second" } \\
\text { biotechnological } \\
\text { revolution }\end{array}$ & $\begin{array}{l}\text { Romanticism and } \\
\text { idealism }\end{array}$ & $\begin{array}{l}\text { The idea of } \\
\text { evolution }\end{array}$ \\
\hline$\sim 50$ & $\begin{array}{l}\text { Environmental } \\
\text { concerns }\end{array}$ & $\begin{array}{l}\text { "Third" } \\
\text { biotechnological } \\
\text { (or "green") revolution }\end{array}$ & $\begin{array}{l}\text { Phenomenology } \\
\text { existentialism }\end{array}$ & \multirow{2}{*}{$\begin{array}{l}\text { "Third" } \\
\text { scientific } \\
\text { revolution } \\
\text { Emergence } \\
\text { biotechnosciences }\end{array}$} \\
\hline$\sim 25$ & Globalization & $\begin{array}{l}\text { "Fourth" } \\
\text { biotechnological } \\
\text { revolution (or biotech } \\
\text { revolution proper) }\end{array}$ & $\begin{array}{l}\text { Emergence of } \\
\text { bioethics }\end{array}$ & \\
\hline
\end{tabular}

The table indicates a number of important turning points ("revolutions"), the most important ones being a series of four "biotechnological revolutions": dramatic shifts in the history of food production, namely the Neolithic revolution ( $\sim 10,000$ years ago), the industrial revolution ( $\sim 250$ years ago), the "green" revolution $^{2}$ ( $\sim 50$ years ago) and, most recently, the biotech revolution based on the molecular life sciences and genomics. Beginning as a laboratory phenomenon focusing on micro-organisms in the 1970 s, the biotech revolution spread to the outside world of plant breeding and food production from the 1990s onwards. For those who use the term "biotechnology" in a general sense, the Neolithic revolution represents the "first" biotechnological revolution. For those who use it in a stricter sense, there is only one biotech revolution and it occurred just a few decades ago.

While the term "biotechnology" is highly contentious, the term "revolution" is disputable in its own right. Rather than to a single eruptive event, the term refers to slowly emerging processes dispersed through time. The Neolithic revolution was certainly revolutionary in its impact, involving dramatic transformations of human life. Instead of gathering, hunting or fishing for their food, human beings now began

2 The dramatic increase of biomass in the 1950s and 1960s due to the introduction of artificial fertilizers and pesticides, allowing food production to keep pace with worldwide population growth, but with disastrous environmental consequences. 
to produce it themselves, thus basically altering the trophodynamics of human existence. This has been seen as the dawning of human freedom by some, and as its downfall by others. But it was in reality, as far as historians can tell, a slowly evolving process rather than a sudden upheaval. The revolution proceeded "at an imperceptible pace" (Jones 2001, p. 94) and a thousand years after the first domesticated crops appeared, the affected landscapes were far from transformed, and hunter-gatherer communities were still wide-spread. In Europe the diffusion was "surprisingly discrete" as well, with negligible impact upon its woodland canopy for millennia. Yet, it "changed the course of history forever" (Jones 2001, p. 104). The agricultural pioneers who brought about the first biotechnological revolution probably did not see themselves as revolutionaries or as people living in a time of upheaval. Rather, we are the ones who retrospectively attach the term revolutionary to events that must have evolved much more gradually and tentatively that the research-driven transformations of our own time. The more recent the transformative event, the more sudden and revolutionary it appears.

The structure of this article is as follows. In the first sections, the most important events - the most important "cells" in the timetable above-will be briefly outlined. Notably, I will indicate why, until quite recently, agriculture, science, and philosophy (including ethics) developed virtually in complete isolation from one another. Four events will thus be highlighted: (a) the Neolithic revolution; (b) the first "scientific revolution" (i.e., the birth of Greek philosophy); (c) the Christian epoch, and (d) the "second" scientific revolution (dawn of modern science). I will show how in modern times science, agriculture, and philosophy increasingly began to converge. Once the timetable has been sufficiently elucidated, I will proceed to explain how this historical backdrop may help us to understand and address the difficulties we experience when it comes to conceptually grasping the meaning of the two key terms of the current biotech debate, namely "biotechnology" and "naturalness."

\section{Expanding the Temporal Horizon: The Neolithic Revolution}

Food is the essence of what we are (we are what we eat), but in order to really acknowledge its importance, philosophers must learn to think in terms of a different timeline, an expanded temporal horizon. For ancient Greek philosophy, time was experienced in terms of the present. Past and future did exist, but were never very distant. Greek culture suffered from a kind of myopia or temporal near-sightedness (Spengler 1918/1923, p. 10 ff). For nineteenth-century philosophers like Hegel or Nietzsche, history had become tremendously important, but only history in the sense of written history, covering a mere $1 \%$ at most of the narrative of Homo sapiens, and with a bias towards certain well-documented aspects of our culture. For contemporary philosophical debate, the temporal dimension has to increase significantly once more. The research into the Neolithic revolution, moreover, is subject to revolutionary change itself, due to the emergence of novel research practices that intend to bridge the traditional dichotomous gap between the "sciences" (studying "nature") and the "humanities" (studying "culture"), such as 
bioarchaeology (Jones 2001), environmental archaeology (Albarella 2001), human palaeoecology (Butzer 1982), and population genomics (Cavalli-Sforza et al. 1994/ 1996). Analysis of cultural phenomena, ranging from language to art and artifacts, is increasingly complemented by ecological and genomics research concerning the history of genomes of humans, plants, and animals in the context of their ecological environments, while the inquiry into early human history is developing into the study of evolving ecosystems shaped and inhabited by humans. The following historical overview builds on these emerging sources.

The Neolithic revolution began $\sim 10,000$ years ago, more or less simultaneously in various parts of the world, in isolation from one another, such as Mesopotamia and Egypt, North and South China (along the Yellow and the Yangtze River), the Indus valley, West Africa (Fuller 2005), Mexico and the Andes highlands (CavalliSforza 1993/1995). From there it gradually undulated into other environments, such as Europe. At various parts of the globe, the face of the earth began to change as human beings began to systematically modify their natural environments through wilderness clearing and reclamation. It was a moment of awakening, as it were, of mankind as a whole. The simultaneity of these worldwide changes suggests a common external factor in the form of global climate change (Cavalli-Sforza 2000/ 2001, p. 97). As humans and animals found themselves united in their effort to circumvent post-glacial draught, former hunters became cultivators and domesticators in their retreating oases (Childe 1936). Every region involved produced its own typical domesticated plant form-a plant that gave the region in question an identity, a face, so to speak-making use of the wild types available: cereals in the Middle East, millet in the Northern parts of China, rice in South China, maize in Mexico. The civilizations concerned became wholly dependent upon a small number of key species (Jones 2001, p. 80). Eventually, around 5,000 years ago, extended parts of the world including China and Europe had become real agricultures where agriculture flourished and constituted the basis of societal existence.

Indeed, when it comes to defining what is meant by the Neolithic revolution, agriculture is the key. It notably involved the cultivation of plant forms, the use of micro-organisms for processes such as fermentation, and the domestication of animals. Human existence changed from a nomadic life-style of hunting and gathering into a sedentary existence. Human beings began to settle down. It involved, in other words, a process of self-domestication (of "housing" ourselves). The large majority of mankind came to live in agricultural settlements-rural villages - where virtually everyone became directly involved in the process of food production with the help of agricultural contrivances and techniques (cultivation, domestication, fermentation, food preservation, etc.).

No "science" was involved in this, at least not in the modern sense of the term, as formally tested, evidence-based knowledge. The knowledge of farmers applying biotechniques such as crop selection or fermentation was of a practical nature, transmitted in oral formats and often connected with animistic cosmologies-as is still apparent for instance in the pre-scientific term for alcohol: spiritus. It was only when Lavoisier outlined the chemical composition of what he termed "alcohol," and, subsequently, when Pasteur elucidated the microbiology of fermentation, that the production of beverages such as beer and wine could become science-based and, as a 
consequence of that, industrialized. But human beings had been successfully developing and using fermentation and other techniques worldwide for millennia. Praxis (practical knowledge) preceded scientific inquiry stricto sensu. It was only in the context of the Industrial revolution that science and technology began to merge and fermentation became an evidence-based industrial practice rather than a domestic activity.

Thus, the CHP, emerging as a consequence of the Neolithic revolution, fared fairly well without science. Moreover, it was a form of life that affected virtually all dimensions of human existence. First of all, it gave rise to a population explosion, as the population level increased dramatically and exponentially (Childe 1936, p. 40; 1942/1946, p. 59). Farmers could afford to support large families and agriculture made high birth rates both "feasible and desirable" (Cavalli-Sforza 1993/1995, p. 133). In comparison to the life-style of hunters and gatherers, the rural village offered a relatively protective environment, less physically challenging. Moreover, whereas hunters and gatherers formed bands and clans of limited size, the new existence encouraged the emergence of large-scale social structures, with cultivated rural regions centering around huge cities. Humans now rigorously controlled the way in which plants and animals developed and reproduced within plots that were under the sway of human action. Large and complex environments were created within controlled landscapes (Jones 2001, p. 80). Large groups of people were needed for irrigation projects or for cultivating wasteland areas. The land on which "the great cities of Babylonia were to rise had literally to be created" (Childe 1936, p. 121). The small-scale group dynamics of nomadic clan life were replaced by more sophisticated forms of politics: the art of managing large numbers of people in extended regionsinvolving all the problems of long-distance governance, through developing new techniques of administration, and these not only included large-scale irrigation projects and construction projects (monuments, palaces, temples, city-walls, etc.), but also auxiliary crafts such as computation and writing. Computation was needed for regulating practices of storage, taxation, and distribution, for example, and writing emerged as a communication tool and as a mnemotechnique for information storage and exchange over large distances and between generations. Whole landscapes were "domesticated" by means of technologies for water management (irrigation and flood control) through large-scale collaborative efforts. And every region involved not only developed its own typical plant form, but also coined its own type of script. Thus, the Neolithic revolution created three types of socio-spheres of increasing size, first of all the rural village (the Neolithic revolution stricto sensu), subsequently the regional city (the "urban" revolution, 5,000 years ago), and finally the emergence of empires encompassing a whole world within its sphere of influence $(\sim 2,500$ years ago).

Thus, the Neolithic revolution provided the ecological foundation of the great civilizations that began to emerge in the "affected" regions (Jones 2001, p. 86). It was a "biotechnological" revolution that involved dramatic cultural changes, notably the development of new cognitive, social, and communicative skills. Social life became much more differentiated in terms of class and gender. In fact, social differences began to solidify into quasi-natural categories - and a host of social roles emerged, often associated with particular technologies and skills. Those not directly involved in producing food themselves, notably the elite in charge of managerial and governing tasks, became dependent on the surplus produced by farmers (Childe 1942/1946, p. 
62). Childe (1936) even goes so far as to argue that the Neolithic revolution that began in illiterate rural areas came to a standstill in the literate centers of the urban revolution it created, where concrete interactions with nature and accumulative technological improvements gave way to scholarly learning and metaphysical cosmology (p. 259). Be this as it may, food production was the decisive factor in determining the type of life human beings began to develop. The CHP as a way of life settled itself to such an extent that it came to be seen as our natural way of being-in-the world. At a certain point, it became difficult to imagine a different kind of life for humans. This is reflected, for instance, in the Bible Book Ecclesiastes. Mankind works and toils, on a seasonal basis, harvesting and sowing. To everything there is a season, everything and everyone has its proper place, nothing ever really changes, human existence has become fully stabilized into the "natural" way of life.

Yet, at the same time, this "natural" common pattern can be seen (from a biological and evolutionary perspective) as a deviation from nature, from the more or less natural forms of existence that had flourished ever since Homo sapiens came into this world. Historically speaking, the CHP merely covers $4 \%$ of human history. From an evolutionary (species) perspective it is an "unnatural" deviation, a cultural "mutation," a new beginning. The CHP produced a new view of nature, in which everyone and everything occupies its natural place, a cosmology that not only reflected the new way of life, but also made it seem natural and therefore legitimate, as if nature and human existence had always been this way, and would always remain basically the same.

\section{Why Food Production was not Always Regarded as an Issue of Philosophical Concern: The Birth of Philosophy}

Twenty-five centuries ago (around $500 \mathrm{BC}$ ) another astonishing event took place: mankind was suddenly visited upon by a cultural mutation, an intellectual epidemic, the dawning of human self-consciousness. All of a sudden, the world began to think, to reflect (Jaspers 1949; Störig 1961). It affected the intellectual avant-garde at various locations more or less at the same time: Confucius (551-479) and Lao Tse in China were contemporaries, more or less, of Buddha in India (563-483), Jeremiah and Zoroaster in the Middle East, and of the early Greek philosophers such as Parmenides and Herakleitos (both born about 540 BC) in the West. As Jaspers and Störig argue, it is difficult to see this synchronicity, this global awakening at different locations more or less simultaneously and independently from one another, as sheer coincidence. Yet, the intellectual transformation did not involve a biotechnological or agricultural revolution. Mankind had already settled into its “common" pattern. Neither Lao Tse, nor Buddha, nor Jeremiah, nor Parmenides came to revolutionize agriculture. What they developed was an ethico-philosophical stance towards the CHP as an omnipresent cultural environment, an attitude of detachment and equanimity. They preached a life of contemplation, in the center (Plato, Confucius) or in the folds and margins (Lao Tse, Herakleitos) of agrotechnical societies, not a transformation of (agro)technology as such. 
In the context of this global awakening, ancient Greek philosophy and mathematics came into existence-a process of rationalization known as the "first" scientific revolution. Mathematics became a rational endeavor based on formal proofs, rather than on computational techniques, as had been the case in the agricultural kingdoms of Mesopotamia and Egypt. Thus, a practical knowledge form became "science" (Boyer 1968). Most ancient philosophers belonging to the first generations of "lovers" and "teachers" of wisdom were of aristocratic inclination, or even descent. They were not directly involved in the process of producing food and other life-sustaining products. Many of them were city-dwellers (that is: food consumers) or "masters," representing the estate managers section of society, preferring to live an idle life, despising manual labor, as well as those who were actively involved in working with their hands. ${ }^{3}$ These first philosophers were eager to leave the toils of agricultural labor to others, notably women, slaves, and rural farmers, as carriers of the CHP. This is reflected in their philosophy, which strived to remain "pure"- a philosophy of contemplation, not at all a reflection on worldly, mundane forms of existence, nor on concrete interactions with natural environments or with the forces and dynamics of nature. Rather, nature was seen as kosmos, a perfect order in which everything and everyone occupies a more or less natural position-with the gentleman-sage placing himself at the center of the universe.

The influence of these ancient "masters" on centuries of philosophical thinking has been tremendous and is still noticeable today. The basic theme of the ancient master-philosophers when it came to reflecting on food was temperance (Zwart $2000,2005)$. This is quite understandable, from the point of view of the ancient Greek (or Roman) "gentleman-philosopher." First of all, it is understandable that their focus was on consumption, rather than on production. Anything that was involved in food production was largely ignored by a philosophy of contemplation. Some managerial skills were involved in the management of human resources, no doubt, and master-philosophers like Plato and Aristotle were eager to point out why their supposedly more rational fellow-aristocrats could be entrusted with directing the lives of less rational and less autonomous individuals (such as women and slaves) that made up the bulk of the human work force of the day, but basically, food production was beyond their scope and sphere of interest. Food, from a Greek aristocratic point of view, and from the point of view of city-dwellers and surplus consumers such as Socrates or Diogenes the Cynic, basically meant food consumption. In the face of wealth and abundance, the mark of rationality and autonomy was temperance, the virtuous mean between two extremes, both of which were seen as not befitting a gentleman, namely deprivation and excess (Aristotle 1926/1982; Cf. Foucault 1984a, b).

A significant part of the ethical discourse of ancient philosophy on food can thus be seen as iterations elaborating this one repetitive theme of temperance. Living a life of temperance was regarded as a way to safeguard one's autonomy vis-à-vis bodily desires and, more importantly even, as a means of distinguishing oneself

\footnotetext{
${ }_{3}$ According to Plato (1930/1999), those who provide food and whose strength of body can be deployed for toil are an inevitable part of the polis but "not worthy of our fellowship" (Republic, $371 \mathrm{D})$.
} 
from the anonymous majority of mankind-the many, hoi polloi. Food production was, quite literally, outside the "sphere" of aristocratic thinking. The things that occupied their minds were far removed from the worries of mundane and daily life. They developed a "platonic" view on food-although Aristotle every now and then took up some of the more concrete issues, for instance by demonstrating, with the help of Greek mathematics, why aristocrats were entitled to consume a relatively large amount of material resources. ${ }^{4}$ In contrast to this, the ethic of small-scale hands-on rural agriculture was captured in other literary genres outside "high" philosophy, such as Aesop's fables or fragments of poems and plays by "minor" authors, where the small farm is described as the most rightful property for us to own, gently yielding everything our human nature needs (Longo 2001).

To the extent that the emergence of rational thinking did have practical consequences, the impact was mainly on the political domain, placing the policies and technologies of administration on a more rational footing. Philosophers such as Plato, Aristotle, or Confucius were greatly interested in ethics and governance, and the intellectual revolution that they instigated would eventually stimulate the emergence of large-scale political entities, such as the Roman Empire and the Han Dynasty (202 BC-AD 220). Although they were highly influential as political philosophers, it was only indirectly, through politics, that their activities eventually affected the ways in which agriculture came to be organized.

Plato and Aristotle did have an interest in nature as such, but not in what we nowadays would call "applied" research fields or anything resembling the contemporary biotechnosciences. Greek scientific thinking, like its counterpart in China, remained metaphysical cosmology: human existence, both individually and politically, was seen as embedded in a cosmological cyclical whole, a kosmos. Concepts like progress on the basis of technological development did not have a place in such a view. It entailed an ethic of equanimity rather than change. Their thinking conveyed the idea that mundane empires should reflect the harmony and stability of heavenly spheres, a pivotal source of inspiration for the construction of huge empires, large-scale political unities encompassing worlds rather than nations, based on agriculture. Meanwhile, the CHP basically remained what it was, undisrupted. Agricultural life continued to provide the ecological basis of life. And although agricultural technologies became more sophisticated and refined over time, they did so gradually and accumulatively and at a relatively slow pace, through verbal and informal practices of communication. As Childe (1942/1946) already indicated, from an early stage onwards, and in the West as well as in the East, the rural crafts of agriculture and the urban (elite) crafts of reading and writing became divorced, so that written history conveyed only a very patchy and incomplete record of societal history (p. 118/9). Only a limited number of knowledge forms became subject to writing, preferably those that were most "divorced from practical life," such as high philosophy and pure mathematics (1936, p. 213)..$^{5}$ Thus, the process of

\footnotetext{
${ }^{4} \mathrm{Cf}$. his views on distributive justice: "[J]ustice involves [two persons and two shares]. If the persons are not equal, they will not have equal shares; it is when equals possess or are allotted unequal shares, or persons not equal equal shares, that quarrels and complaints arise" (Aristotle 1926/1982; V. iii. 6-8).

5 "In entering the school the pupil turned his back on plough and bench... Learned men were apt to turn to books in preference to nature" (Childe 1936, p. 213).
} 
rationalization by the enlightened elite affected mathematics and cosmology more than biotechnology and agriculture. Academic disciplines tended to be of a lofty nature. Although they included interest in managerial issues, the world of food production was taken for granted. For centuries to come, the CHP remained more or less in place.

The focus on the elitist theme of temperance does not make these ancient views and ideas about food irrelevant, but we must place them in their proper historical perspective. Contemporary philosophy can no longer afford to ignore issues involved in food production. By allowing food-notably its production-to occupy a central place on our agendas, we as philosophers of the present emphatically distance ourselves from our aristocratic predecessors of long ago. Not by discarding ancient Greek philosophy altogether, but rather by seeing it as a particular position in the context of a long-winded historical drama of doing and thinking with regard to food. Until recently, however, Greek philosophy was seen, not as a mere chapter in the history of thought, but rather as its true beginning, setting a standard for philosophers of later times. In order to understand the present, it became established practice, notably among continental philosophers, to use the ancient world, exemplified by the writings of philosophers like Plato, as a critical mirror.

That is why, in order to clarify the meaning of food in human life, we have to take the historical exercise much further, developing a more extended view on human history. Philosophy as a discipline has to undergo a significant increase of scale. The true beginning for a "history of the present," the real origin of the processes that eventually gave rise to the here and now, is not the dawning of the rationalistic worldview around 500 B.C., but rather the Neolithic revolution that occurred millennia before that time, opening up some of the crucial dimensions that have characterized human existence ever since, such as agriculture, writing, and politics. The Neolithic revolution resulted in the emergence of the CHP as a way of being that was more or less seen as natural and given by the master-philosophers of ancient Greece. For them, this form of life was simply "there," and this allowed them to virtually ignore its material aspects in their philosophies. They could afford to leave their slaves and laborers chained to their cave-like existence of daily toil, while they themselves indulged (in their gardens and sport facilities) in reflections on the place of friendship, temperance, and contemplation in what, undoubtedly, must have been a very good life.

\section{Christianization: On Metaphysics Becoming Natural}

An important document that contains a concise account of the Neolithic revolution is the Bible Book Genesis, either in its original version or in more recent adaptations such as John Milton's Paradise Lost. Initially, mankind leads a life of gathering and leisure, and human existence has not yet evolved into a sedentary way of being. The first humans roam about without a fixed dwelling place, but as soon as their proverbial Paradise is lost and they are banished from Eden, the world dramatically changes overnight. They have to leave their "native soil" with its "walks and shades," its beautiful flowers and pleasant climate, in order to migrate into a 
seemingly unfriendly landscape where toilsome labor awaits them-where "the field to labor calls us now," as Milton phrases it (1962, Book XI, 171-172) and where they have to "till the ground" (261) in a world that is obscure, wild, inhospitable, and desolate (306). Eventually, however, fields, villages, and cities emerge in this landscape, and human beings multiply (XI, 17).

Interestingly, while the Neolithic revolution is depicted as punishment in Genesis, modern authors such as Kant (1786/1971), and to a certain extent Milton, suggest that it was in fact a liberation, the beginning of the true history of mankind. In Paradise the first humans more or less still lived the life of "human animals," passive consumers, not yet responsible for the production of their own food. The debate between rational humanists such as Kant, seeing the emigration out of Eden as the dawning of human freedom, and Romantic counterparts such as Jean-Jacques Rousseau, rather interpreting it as the beginning of enslavement, still continues and there is an element of truth in both accounts. By becoming food producers, human beings emancipated themselves from their dependence of natural resources. On the other hand, the Neolithic revolution gave rise to social differentiation and the emergence of phenomena such as class, property, and division of labor. Social stratifications assumed the status of "natural" social categories embedded in the CHP and supported by metaphysical cosmology.

As Karl Jaspers rightly pointed out, there was no technology, let alone "biotechnology," in Paradise (1949, p. 153). The escape from Eden coincided with its emergence. From now on, mankind labored and toiled to produce edible cereals, as the earth herself brought forth only thorns and thistles. And this involved cognitive activities such as planning and calculating. Adam, Eve, and their sons became active in farming and animal husbandry, producing their own food through cultivation and domestication. A dramatic population increase resulted: mankind began to multiply exponentially, encouraged by God Himself to be fruitful, to multiply, to bring forth abundantly. Beget children, raise cattle, multiply! was God's basic moral maxim in Genesis. Cities like Babel came into existence, involving large-scale collective efforts, notably in the sphere of architecture (albeit apparently not very successful in the beginning due to problems of communication and governance of human resources). The majority of human beings, however, like Abraham and his clan, lived a rural life, as animal domesticators or crop cultivators. The Bible as a whole describes how, after an initial period of conflict and drama, the agricultural life-style (CHP) gradually stabilizes itself. Mankind as such becomes domesticated as it were. In the Gospels, agricultural existence, a life of sowing and harvesting, of preserving (notably through fermentation) and distributing food, is the inevitable way of being-in-the world for mankind. The Roman Empire introduces new techniques of power, based on monetary systems, civil legislation, road building, and tax paying, but the daily world of agriculture is hardly affected.

Christianity came to play a important role in the history of producing and processing food during the "medieval" period, when monastic orders combined an interest in Aristotelian cosmology with systematic programs for agricultural enhancement. After the Fall, the natural way of life had to be restored by wellorganized stewardship through self-discipline and labor. Monastic orders had a tremendous impact on the development of biotechnologies and landscape 
transformation, from Saint Benedict (480-547) in the early Middle Ages up to the era of Gregor Mendel (1822-1884). They were responsible for programs of cultivation, reclamation, and wilderness clearing, but also for developing new techniques for fermentation and food processing, as well as for developing disciplined and methodical lifestyles, much more disciplined than the behavioral patterns that flourished in rural environments. Thus, monastic orders played a key role in bringing about the population growth in Europe during the second half of the Middle Ages when agricultural innovations began to reverse the economic decay that had followed the collapse of the Western Roman Empire. Yet, even more dramatic has been the impact of the modern sciences that came into existence during the so-called "second" scientific revolution.

\section{Scientific Revolutions: The Convergence of Agriculture and Science}

Rather than with mundane realities, ancient Greek philosophy and mathematics had been occupied with ideal objects of contemplation. "Real" science-scientia experimentalis-began somewhere between the fourteenth and the seventeenth century. A drawback of the sudden dramatic "leap" (Jaspers 1949) of ancient Greek thinking into science had been that the practical and material realms of life were eclipsed and by-passed more or less. Many centuries later, the German philosopher Hegel in a famous passage in his Phenomenology of the Spirit indicated that, in order to acquire real knowledge about the natural world, one has to leave the position of the master, the position of idleness-merely contemplating and idealizing nature - in order to become really, actively, and interactively involved with nature (1807/1973, pp. 145-154)—for instance by designing and conducting experiments - thinking with your hands, using contrivances and tools in order to force nature to reveal her secrets, thus acquiring real power over nature-the modern "Faustian" power to modify natural processes.

Initially, the "second" scientific revolution" assumed an academic profile comparable to the first. Yet, from the very onset, it involved a much more active stance towards nature, due to the fact that its core idea was that of conducting an experiment. In the context of an experimental trial, manipulation precedes observation. In ancient Greece, observation of natural phenomena had been connected with reverence and wonder, but modern researchers began to interact in a less respectful and more manipulative vein with objects of research. The guiding idea of the second scientific revolution was that nature can best be understood through manipulation, while a better understanding will allow us to modify and

\footnotetext{
6 The terms "first" and "second" scientific revolution ("Revolution der Denkart") were introduced by Kant (1781/1975) in the Introduction to the second edition of his Critique of Pure Reason. The second revolution began in astronomy as the "Copernican" revolution (Copernicus, Galileo) and spread from there to physics (Newton, Boyle) and chemistry (Lavoisier). It relied on the introduction of new contrivances and tools (such as microscope, etc.) and its basic idea was that of conducting an experiment, that is, the idea that manipulation, rather than passive observation, leads to knowledge. It can be argued, however, that the Scientia experimentalis originated much earlier, in the fourteenth century, with the work of Roger Bacon, Cusanus, and others (Spengler 1918/1923).
} 
master life and matter more effectively. The new sciences were motivated by a Will to Power, to use the Nietzschean phrase. This became clear as the new knowledge began to migrate from contained environments such as private academies and smallscale laboratories into the real world of labor and productivity. In the course of the eighteenth and nineteenth century, modern science began to change the human world dramatically, notably the world of human labor. This coincided with a dramatic population increase, one that equaled the increase associated with the Neolithic revolution (Childe 1936), and eventually led to a profound disruption of the CHP. The surplus population of rural areas began to migrate from rural environments into the quickly expanding industrial cities, constituting a new type of human beings, the labor force in the form of the urban human "masses." Books like Das Kapital by Karl Marx and Surveiller et Punirby Michel Foucault (1975) can be seen as efforts to describe the transformation of rural populations into the "labor force," the "human resources" of modern industrial times.

The basic disruption consisted in the fact that, from now on, the majority of individuals was no longer directly involved in the process of food production. The two basic dimensions of food, namely production and consumption, became disconnected. The urban masses, as food "consumers," became increasingly dependent on industrial food "producers," and on novel food products produced by the food industry on a science-based footing. Beer, bread, butter, and meat dramatically changed from home-made entities into industrial products-into commodities (Zwart 2005). Producers no longer produced products for their neighbors or themselves, but rather for a market of abstract, anonymous consumers, in competition with rival producers. According to Romein and Romein-Verschoor (1954), the industrial revolution constituted a real deviation from the CHP as it had existed so far, placing Europe in an exceptional position in comparison to other regions of the world, notably Asia (Romein 1956), where the CHP continued to exist for quite some time.

In the context of this deviation, human life changed in other ways as well. Time, as a basic dimension of human existence, suddenly changed. As Karl Marx explained in Capital (1867/1906), the working day no longer coincided with a "natural" day"natural" in the context of the CHP. From now on, it could be quantified and objectified-defined in term of exact time indicators such as hours and minutes, rather than in more "natural" terms such as sunrise or sunset. Time itself became modifiable and negotiable as it were, a variable quantity (pp. 256-257). The "natural" distinction between day and night became obsolete and had to be replaced by an exact definition of what constitutes a working day, by a negotiable demarcation between productive and reproductive time-as well as between the context of food production (in factories) and the context of food consumption (in urban domestic environments). As Marx describes in Chapter 8 of his famous book, fierce struggles evolved over the definition of a "natural" working day. Initially, it was said to contain twelve hours. At a certain point, however, factory owners managed to extend it to sixteen hours. The labor movement protested against such a violent transgression of "natural" restrictions on the exploitation of bodily resources and eventually, it was reduced to eight hours. Yet, the awareness that temporal demarcations are arbitrary in principle and open to negotiation became a fact of life. 
Finally, the twentieth century has been regarded, and rightly so, as the stage setting of the "third" scientific revolution, studying the building blocks of matter and life, beginning around 1900 in physics (the quantum concept, quantum physics, theory of relativity, etc.) as well as in genetics, spreading from there to chemistry and computer science and converging into the life sciences around the middle of the century (Schrödinger 1944; Watson and Crick 1953). In various ways the "third" scientific revolution (resulting in nuclear physics on the one hand and in biotechnology as its biological counterpart on the other) has affected our views and practices concerning the production and consumption of food. Within decades, it has given rise to transformations that are generally regarded as revolutionary. As Jaspers argued, the introduction of nuclear power, as the most visible and tangible outcome of the "new" physics that emerged during the first decades of the Twentieth Century, was a second "Promethean" revolution, comparable in historical significance to the invention of fire and everything this implied for the process of anthropogenesis, the coming into being of mankind. The Promethean revolution notably gave rise to pyrotechnology as a primeval form of environment management (forest clearance, hunting practices, nomadic agriculture, etc.) that dominated human existence for millennia (Moore 2001). The biotech revolution that occurred during the final decades of the century was rather the counterpart of the Neolithic revolution.

The biotech revolution in a strict sense was preceded by the so-called "Green" or biochemical revolution (the "third" biotechnological revolution) emerging in the wake of World War II and involving the introduction of herbicides and artificial fertilizers, thereby significantly boosting agricultural production levels to unprecedented heights, in order to keep pace with the global population explosion that was already taking place at that time (Conway 1998). The subsequent transformation known as the biotech revolution affects both ends of the food chain: production as well as consumption. In the context of food production it resulted in the introduction of genetically modified crops, produced for a global food market, where the distance between production and consumption increases dramatically. In the context of food consumption, consumer "empowerment" has become an important issue: the idea of allowing individual consumers to manage their own health and to develop their own consumer identity, on the basis of labeling and (evidence-based) information, even allowing producers and consumers to tailor food products to consumer genomes on the basis of an improved understanding of how food affects and interacts with our bodies and our genomes. In order to put these latter developments in their proper context, and to understand the normative controversies that have erupted, the historical backdrop outlined above will prove of pivotal importance. In the following sections, I will first discuss the role of "biotechnology" in the context of contemporary food production. Next, I will discuss the role of "naturalness" in the context of contemporary food consumption.

\section{Biotechnology and its Discontents: Transformation of Food Production}

As was indicated, two apparently incompatible narratives concerning the role of biotechnology in food production evolved. The first one emphasizes continuity, 
arguing that food production (cultivation of plant forms, "domestication" of microorganisms such as yeast, etc.) began millennia ago. Humans have been modifying and domesticating life forms ever since the Neolithic. The current biotech revolution is yet another chapter in an on-going story. The second narrative emphasizes that there is something fundamentally new and unprecedented-or even uncanny -, about the new technologies of life: they are providing us with fundamentally new forms of biopower. While the first narrative is often propagated by scientists and biotechnology experts (cf. Henry Miller 2007), the second one tends to be disseminated by biotech critics such as Jeremy Rifkin, a prominent protagonist of the discontinuity-thesis, notably in his now classic book The Biotech Century (1998/1999) that can be regarded as representative of (setting the standard for) the discontinuity discourse.

Although Rifkin is of course clearly aware of the fact that humans have been modifying life forms ever since time immemorial, he nonetheless vehemently argues that biotech confronts us with unprecedented challenges. According to Rifkin, global agriculture finds itself "in the midst of a great transition in world history" (p. 2), one that "raises more troubling issues than any other revolution in history" (p. xiii). Our way of life is likely to be more fundamentally transformed in the next several decades or so than in the previous one thousand years (p. 1). Eventually the new revolution may lead to "the elimination of the agricultural era that stretched from the Neolithic revolution some ten thousand years ago to the green revolution of the latter half of the century" (p. 2). The ability to isolate, identify, and recombine genes is making the gene pool available, for the first time, as primary raw resource. That means that we are now "really and effectively" manipulating living materials. Biotech represents an abrupt deviation from the way of life that has existed for millennia: "In little more than a generation, our definition of life and the meaning of existence is likely to be radically altered. Long-held assumptions about nature, including our own human nature, are likely to be rethought" (p. 1). Indeed, according to Rifkin, biotech constitutes "the most radical experiment humankind has ever carried out on the natural world" (p. x). It constitutes a "re-seeding" of the world, a laboratory-conceived second Genesis (p. 67). Eventually, it is bound to lead to a biological Tower of Babel, spreading chaos throughout the biological world and drowning out the ancient languages of evolution (p. 70). And although Rifkin acknowledges that human beings have been remaking the Earth "for as long as we have had a history," up to now our ability to re-create nature has been tempered by natural restraints, such as species boundaries. In the course of a long historical process of tinkering and trial and error, nature continued to dictate the terms of the engagement. But the technologies of the genetic age allow scientists to manipulate the world at the most fundamental level. A radical scientific experiment, using the global environment as its test-bed, is underway.

Thus, in order to come to terms with the current revolution, Rifkin's historical point of reference is the Neolithic transition, notably as depicted in Genesis. Rifkin figures as prophet who literally depicts the revolution as a second Genesis. Natural genomes (the basic outcome of Genesis One) have now become raw materials. Moreover, biotech is not the work of individual scientists, but rather evolves through large-scale networks, involving many experts worldwide, that have to be administered, governed and monitored. These large-scale enterprises will change 
the societal landscape as well. As has been the case during the "first" biotechnological revolution, agro-cultural developments are bound to significantly affect society at large. For Rifkin in his role as prophet, these developments will inevitably result in a second Babel, in a series of catastrophic events, a global cataclysm of truly biblical proportions-indeed, he predicts worldwide poverty, infectious diseases, environmental deterioration, and similar apocalyptical disasters.

Yet, for those who prefer to think of contemporary biotech as a continuation and miniaturization of previous human interactions with nature, a rival but perhaps equally compelling view may be developed on the basis of the same ideas. 10,000 years ago, the Neolithic revolution already constituted an experiment with nature in its own right, initially at local levels (notably alongside large rivers) but eventually on a global scale, greatly affecting flora and fauna worldwide. To ask ourselves how we, retrospectively, assess this event seems an almost impossible question to ask, if only because human culture as such-and this includes activities such as scholarly communication and writing biophilosophical articles-would have been unthinkable without it. It would more or less amount to asking ourselves whether we appreciate the fact that we exist at all. Without it, human life would look radically different, if only in terms of the number of people that would be able to maintain themselves. The Neolithic revolution has had dramatic consequences for human existence, as well as for life on Earth more generally, and this will go for the current biotech revolution as well. This does not mean that we should abstain from moving in this direction altogether, if it would at all be possible for such a "decision" to be made. In the case of previous revolutions, such as the Neolithic and the Industrial one, one could argue that initial stages of drama, confusion, and conflict (beginning with the trauma of Babel) eventually gave way to normalization, stabilization, and progress, during which new technologies became "domesticated" as it were, and a "common" pattern, manageable in principle, established itself. ${ }^{7}$ And this same logic may apply to the most recent stage in the history of biotechnology as well. As Cavalli-Sforza argues, genetics was invented during the Neolithic revolution, but reinvented in the twentieth century, by making once again a "giant leap forward" in the power to modify organisms (1993/1995, p. 262). After a period of dramatic intrusion of technologies that are rightfully seen as uncanny and new, a new balance may set in, a new epoch of domestication. Yet, if we take the comparison with the Neolithic revolution seriously, it is unlikely that this will be a spontaneous process. Rather, it will call for active governance and deliberation.

\section{Food Consumption and the Quest for Natural Food}

We are what we eat. This first of all applies to the Neolithic styles of food production that created the CHP as a quasi-natural form of life. But the famous quote remains valid in the more recent past. Patterns of food consumption allow us to assume particular social and cultural identities. As was already indicated, in the course of the industrial revolution, special food products were developed especially for the urban

\footnotetext{
Thus biotechnology (in a general sense) gave rise a social dynamics that was more or less similar to the "punctuated equilibrium" of biological evolution.
} 
masses (meat extracts, margarine, canned meat, factory bread, etc.). By consuming these products, consumers demonstrated their adherence to a particular class (Zwart 2005), but it was not a matter of free choice. The link between food products and social identify was pre-established. In the metropolises (mother-cities) of the present, however, this is changing. Food is not only abundantly available, but we are confronted with a proliferation of food products from all corners of the earth. This sets the stage for the development of new identities, in other words: for consumer empowerment, for new practices of identity-formation and self-constitution through consumer choices. Choosing to consume or not to consume certain food products, for instance because they contain genetically modified ingredients, or meat, or products produced through child labor, allows us to position ourselves politically, and to assume a moral identity.

An intriguing phenomenon in this context is the consumer demand for "natural" food. In ancient times, philosophers like Aristotle gave voice to the idea that the good life is a life "in accordance with nature," He did not mean by that a life close to nature in the rustic or Romantic sense. For Aristotle, the natural life was one of equanimity and harmony, the life of the gentleman-sage, of detachment, as far removed as possible from concrete interactions with nature and a rural existence, toiling for one's daily bread. In contemporary debates on food consumption, "natural" still tends to be equated with "good" by many, but what do we mean by it? Concepts such as "nature" and "natural" have become notoriously problematic. One of the problems is that these concepts can easily be abused, for instance by presenting certain forms of social or gender inequality as "natural."

Against the backdrop of our timetable we may distinguish between three incommensurbale interpretations of "nature" or "natural." The interpretation that emerged in the context of the CHP differs from the interpretation brought forward by ancient Greek philosophers (notably Aristotle) and even more so from more recent scientific interpretations. If the CHP is regarded as the "natural" way of being for humans, everything that is part of this way of being-in-the world is bound to be seen as "natural." In the case of Aristotle, however, the concept of the "natural" was embedded in ancient Greek cosmology, the vision of the world as a perfect order. Finally, in the scientific interpretation, anything that is disclosed by scientific research, be it evolution or the functioning of genes, is "natural." Let me elaborate this somewhat further.

In many debates about food, the CHP still functions as a basic frame of reference when it comes to defining what should count as the natural life. In Tolstoy's great novel Anna Karenina (1878/1984), city-dwellers seem to revivify when they allow themselves to adopt and endorse a more "natural," that is: agricultural form of life, tilling the soil and consuming "natural" food. Apparently, this is what human life is meant to be, how human beings were meant to live. From a CHP perspective, while traditional forms of crop cultivation (based on selection and hybridization) are regarded as "natural," genetic manipulation (taking place in high tech laboratories rather than in rural domestic environments) will be regarded as deviant. The CHP also gave rise to other ideas about naturalness, such as the idea of a natural division of labor among the sexes as well as the idea of a natural working day and a natural life-span for human beings-in short the idea that, to everything, there is a season. 
A similar tension troubles the debate concerning the naturalness (or integrity) of domestic animals. What do we mean when we say that in the context of animal husbandry for instance, animals should be treated in such a way as to permit them to behave naturally? As Segerdahl (2007) has argued, natural behavior of farm animals is not a "biological" concept, since from a biological point of view the animals' behavior has already been changed through domestication. Rather, naturalness is part of a normative ideal that favors animal-caretaker interactions as it emerges in traditional rural settings over the living conditions of domestic animals in the context of evidence-based production and intensive farming ("factory farms").

This is in many respects a different kind of naturalness than Aristotle had in mind. For him, the natural order of things was connected with metaphysical cosmology, notably the idea of the world as a $\kappa o ́ \sigma \mu o \varsigma$ in which everyone and everything has (or strives to reach) its natural place. According to Aristotle, this universal order should be reflected in politics and ethics as well, resulting in the conviction that slavery and various other forms of social inequality should be regarded as "natural." It was, so to speak, a top-down view on nature through which the gentleman-sage explicitly distanced himself from views of nature that tended to be connected with concrete interactions with nature-bottom-up views, based on concrete rural experiences rather than on detached reflections. This may well explain why in politics and (biomedical) ethics, naturalness as an Aristotelian norm has been loosing terrain, while in the areas such as food ethics and environmental ethics, naturalness (in the sense of: closeness to nature, placing high value on concrete interactions with nature such as biological farming or hiking) is still regarded by many as a viable argument. Here, the idea of naturalness seems more grounded in practical life, corresponding to the CHP. Although this type of life has been disrupted by a series of technological transformations, the ideas connected with it still seem to retain something of their attractiveness to many-also because, as a countervailing force vis-a-vis rationalization and industrialization, the Romantic movement represented by Rousseau, Tolstoy, and others tended to idealize the CHP when they compared it the tensions of modern urban life-notably the estrangement from food production.

The most powerful iconoclastic destroyer of such conceptions of naturalness, connected with memories and images from disappearing worlds, are the biotechnosciences. As a rule, when scientists speak about nature, they neither refer to the metaphysical cosmology of Aristotle, nor to the domesticated rural nature of CHP existence, but rather to nature in a biologistic sense (Nuffield Council on Bioethics 1999). For them, nature basically means Palaeolithic nature. From this perspective, Neolithic life-styles already constitute a deviation from the natural form of existence as the outcome of biological evolution. The rural village already constituted a postnatural world, a biotechnological artifact, where interaction with nature was based on manipulation (crop cultivation, hybridization, fermentation, etc.).

This explains why, whereas lay publics often tend to see genetic modification as "unnatural" - a view that retains some of the logic of the CHP as a natural form of life-many biotechnoscientists will argue, first of all, that biotechnology simply makes use of processes that nature herself has developed in the course of evolution and, secondly, that insofar as biotechnology is unnatural, mankind has been 
manipulating nature since time immemorial, so that genetic modification "merely" constitutes an acceleration and refinement of more traditional forms of cultivation. Thus, a substantial part of public debate on genetic modification and other forms of biotechnology can be regarded as a clash between incommensurable visions of nature that emerged in various contexts in the course of history. Insofar as "Palaeolithic" or "biological" nature is regarded as natural, as many scientists tend to do, it is difficult to see how nature can provide norms or normative guidance. In primal nature, anything seemed allowed insofar as competitiveness is furthered.

Neolithic nature, on the other hand, already refers to a particular form of human life, a particular form of embedding existence in nature. This vision, therefore, already entails a normative dimension, a view (at least in broad outline) on the good (that is, the "natural") life-although not natural in the biological sense of the term. Indeed, from a "biologistic" perspective, the CHP already constitutes a deviation. And it is no coincidence, of course, that as soon as the CHP was disrupted by the process of industrialization, a new, Darwinian and neo-Palaeolithic vision of nature emerged, based on the idea of competition for limited resources and scarce opportunities-in other words a view of nature that was tailored to human life as it was emerging in the context of industrial society. And this explains why critics of industrialization, such as Tolstoy, argued that the new form of life implied an intrusion or deviation, an "unnatural" form of existence. Neolithic life can likewise be regarded as unnatural, however, in the sense that it is a cultivated, domesticated form of life, the outcome of a series of rather consequential techno-cultural developments. Strictly speaking, it is a deviation from Palaeolithic behavioral patterns as outcomes of our biological evolution, equipping us for a life of gathering and hunting rather than farming. In biological terms, our Palaeolithic genome prepared us for a very different kind of life than we are living, also when it comes to food intake. Exposed to a "Neolithic" lifestyles (cereals intake in combination with sedentary behavior), our bodies (as carriers of "Palaeolithic" DNA) may develop a number of problems.

\section{Palaeolithic Genomes and Neolithic Life-Styles}

Genomics research, notably nutrigenomics, is now claiming that the Neolithic food practices that established themselves in large parts of the world between $\sim 10,000$ and $\sim 5,000$ years ago constitute a deviation from the "natural" human pattern (in a biological sense of the term) that existed for, say, 96\% of human history. Therefore, the food products generated by "deviant" Neolithic production forms are not in accordance with what biologically speaking may be regarded as our natural diet. Although it seems "natural" (from a CHP perspective) to consume our "daily bread," this may not be true for humans as a biological species. In principle the new food products that emerged in the context of the CHP were not tailored to our genomes. A tension was thus introduced between Palaeolithic genomes and Neolithic life-styles, between our genomes as the outcome of our biological evolution and technologybased food regimes as the outcome of techno-cultural developments. The fit between diet and genome was from now on far from perfect. 
Nutrigenomics studies the way in which our genome responds to Neolithic and post-Neolithic forms of food intake. Due to the slowness of biological evolution in comparison to the exponential pace of cultural change, our genome has by and large remained a Palaeolithic one. In Palaeolithic environments, food was often unsafe no doubt, containing microbial or other contaminants, and often scarce, dependent on seasonal fluctuations. Yet, it was (biologically speaking) our natural diet. Modern agricultural environments provide food products that are usually safe and, in most parts of the world at least, abundantly available. They are rich in terms of calories, but often poor in terms of nutrients. During the Neolithic food regime, the range of food ingredients tended to decrease, as consumers became increasingly dependent on one particular core product (such as rice, wheat, maize, or potatoes). The "estrangement" between Neolithic diets and Palaeolithic genomes has been causing an impressive series of so-called "cultural" health problems, ranging from obesity and diabetes to cardiovascular disease (notably Coronary artery disease or CAD) and colon cancer (Eaton and Konner 1983; Cordain 2002; Cordain and Eaton 2005; Muskiet 2005). Obesity especially has been framed as a typically Neolithic health problem, arising from consuming large quantities of cereals and other food products made available by agricultural technologies, in combination with the Neolithic habit of settling down, of becoming sedentary, of "housing" ourselves, thereby gaining weight. The French novelist Rabelais has immortalized the popular, agricultural ideals of the Neolithic revolution in the form of obese, gluttonous, heavyweight giants, Gargantua and Pantagruel. In this bodily ideal, obesity is more or less identified with health and fertility and Rabelais's archetypical giants are icons of a popular literary tradition of long standing, glorifying a rural and agricultural form of life. Yet, in an era in which the physical condition of human resources, notably the "lower classes," is once again becoming an economical issue of concern, notably in the face of an "obesity epidemic," the valuation of fatness has changed (Zwart 2007).

Furthermore, Neolithic diets contain ingredients that (at least for some consumers), are difficult to digest, such as gluten. Gluten intolerance, or Celiac Disease, is again a Neolithic health problem. Although the problem emerged $\sim 10,000$ years ago, it was only identified as such quite recently. Through genomics we begin to understand what we have been doing, during the past millennia, to our bodies and digestive systems by adopting Neolithic life-styles. Collaboration of genomics researchers with archaeologists may perhaps lead to a Renaissance of Palaeolithic food products so that our future diets become increasingly trans-Neolithic, re-tailored to our genomes. The weakness of this view is that it sees the human genome as stable and inflexible rather than plastic and responsive, whereas human life and health must be regarded as the outcome of a complex interaction between genome, lifestyle, and environment. "Epigenomics" is studying the ways in which actual lifestyles are affecting our genome, which continues to change and respond, even during our individual life.

\section{Concluding Remarks}

While the Industrial revolution "estranged" the urban masses from the process of food production, the Neolithic revolution was already a deviation from our 
"natural" form of existence in the biologistic sense of the term. A nomadic life-style gave way to a sedentary one, producing different kinds of food products than had been naturally available. Yet, an intimate relationship was established between production and consumption. The majority of rural consumers were now intensively involved in producing their own food, as well as the surplus resources consumed by the urban and aristocratic elite (sections of society from which philosophers tended to be recruited). This social stratification explains why ancient philosophers tended not to pay much attention to the significance of food production for understanding key features of human existence. Although highlights of ancient philosophy emerged in the context of meals (symposia), even then the focus was on food consumption rather than production.

The Industrial revolution undermined the intimate relationship that had existed in rural environments for millennia between food production and consumption. Europe deviated from the CHP that had established itself almost globally-as Palaeolithic life-styles only managed to maintain themselves under exceptional climatologic conditions (such as exist in Australian deserts or African rain forests). In the West, urban masses became increasingly dependent on industrial food producers, so that restoring consumer autonomy through labeling policies became a major issue of concern. In contemporary societies, food consumption has become a matter of selfconstitution and identity-formation for the many. To a certain extent, it is now up to individuals themselves which idea of embodiment they want to express in their own food practices. They may develop particular forms of consumer behavior in order to position themselves in the context of societal debates, for instance on the moral appropriateness of bioindustrial animal husbandry, or on sustainability and global fairness. Thus, ideally, consumers may once again regain some level of influence over the food production process.

On the other hand, we see a widening of the gap between production and consumption on a globalizing market. Rather than a "global village," where consumers may once again regain control over their own food intake, the global mother-city may become a place where biotechnosciences generate food products that defy rather than facilitate consumer involvement. Rather than providing opportunities for participation, consumers may feel increasingly disenfranchised (Lien and Anthony 2007, p. 413). The Industrial revolution had allowed the West to deviate considerably from the CHP. As a consequence, whereas Europe and China, for example, were still remarkably similar in medieval times, modern Europe was exceptional, as Romein and Romein-Verschoor (1954) have argued. Yet, as the new technologies are now becoming globally available, a worldwide market for food products and food technologies will no longer regard the West as "deviant" (either in a positive or in a negative sense) as new global forms of life, based on globalized food production, are emerging.

Open Access This article is distributed under the terms of the Creative Commons Attribution Noncommercial License which permits any noncommercial use, distribution, and reproduction in any medium, provided the original author(s) and source are credited. 


\section{References}

Albarella, U. (Ed.). (2001). Environmental archaeology: Meaning and purpose. Environmental science and technology library. Dordrecht/Boston/London: Kluwer.

Aristotle (1926/1982). The nicomachean ethics. (H. Rackham Transl). Loeb Classical Library. Aristotle IXI. Cambridge: Harvard University Press; London: Heinemann.

Boyer, C. (1968). A history of mathematics (2nd ed.). New York: Wiley.

Bruce, D., \& Bruce, A. (1999). Engineering genesis. The ethics of genetic engineering in non-human species. London: Earthscan Publications.

Butzer, K. (1982). Archaeology as human ecology. Cambridge: Cambridge University Press.

Cavalli-Sforza, L. (1993/1995). The great human diasporas. New York: Basic Books.

Cavalli-Sforza, L. (2000/2001). Genes, peoples and languages. Berkeley: University of California Press.

Cavalli-Sforza, L., Menozzi, P.,\& Piazza, A. (1994/1996). The history and geography of human genes. Princeton: Princeton University Press.

Childe, G. (1936). Man makes himself. London: Watts.

Childe, G. (1942/1946). What happened in history. Harmondsworth: Penguin.

Conway, G. (1998). The doubly green revolution. Food for all in the twenty-first century. Ithaca: Cornell University Press.

Cordain, L. (2002). The paleo diet: Lose weight and get healthy by eating the food you were designed to eat. Hoboken: Wiley.

Cordain, L., \& Eaton, S. (2005). Origins and evolution of the Western diet: Health implications for the 21st century. American Journal of Clinical Nutrition, 81(2), 341-354.

Eaton, S., \& Konner, M. (1983). Paleolithic Nutrition: A consideration of its nature and current implications. New England Journal of Medicine, 312, 283-289.

Foucault, M. (1975). Surveiller et punir. Naissance de la prison. Paris: Gallimard.

Foucault, M. (1984a). Histoire de la sexualité 2: L'usage des plaisirs. Paris: Gallimard.

Foucault, M. (1984b). Histoire de la sexualité 3: Le souci de soi. Paris: Gallimard.

Fuller, D. (2005). Farming: Stone age farmers of the savannah. In K. Shillington (Ed.), Encyclopaedia of African history. New York: Fitzroy Dearborn.

Hegel, G. (1807/1973). Werke 3: Phänomenologie des Geistes [phenomenology of the spirit]. Frankfurt am Main: Suhrkamp.

Jaspers, K. (1949). Vom Ursprung und Ziel der Geschichte. Zürich: Artemis.

Jones, M. (2001). The molecule hunt. Archaeology and the search for ancient DNA. London: Allan Lane/ The Penguin Press.

Kant, I. (1781/1975). Kritik der reinen Vernunft. Sämtliche Werke in zehn Bänden, III. Hrsg. Wilhelm Weischedel. Darmstadt: Wissenschaftliche Buchgesellschaft.

Kant, I. (1786/1971). "Mutmasslicher Anfang der Menschengeschichte." Sämtliche Werke 9. Hrsg. Wilhelm Weischedel. Darmstadt: Wissenschaftliche Buchgesellschaft, 83-102.

Lien, M. E., \& Anthony, R. (2007). Ethics and the politics of food. Journal of Agricultural and Environmental Ethics, 20, 413-417.

Longo, O. (2001). The fairness of the farm. Ecology and ethics in ancient Greece. In: M. Pasquali (Ed.) EurSafe 2001. Food safety, food quality and food ethics. Third Congress of the European Society for Agricultural and Food Ethics (preprint), (pp. 75-79). http://www.eursafe.org/pdf/plenaryprpts.pdf.

Marx, K. (1867/1906). Capital: A critique of political economy. New York: Modern Library.

Miller, H. (2007). Biotech's defining moment. Trends in Biotechnology, 25(2), 56-59.

Milton, J. (1962). "Paradise lost." In: Poems. London: Dent; New York: Dutton.

Moore, J. (2001). Can't see the wood for the trees. Interpreting woodland fire history from microscopic charcoal. In: Albarella, 211-229.

Muskiet, F. (2005). Evolutionaire geneeskunde: U bent wat u eet, maar u moet weer worden wat u at. Nederlands Tijdschrift voor Klinische Chemie en Laboratoriumgeneeskunde, 30, 163-184.

Nuffield Council on Bioethics. (1999). Genetically modified crops: The ethical and social issues. London: NCB.

Plato. (1930/1999). Republic. Transl. P. Shorey. Loeb Classical Library. Plato V. Cambridge/London: Harvard University Press.

Reiss, M., \& Straughan, R. (1996). Improving nature? The science and ethics of genetic engineering. Cambridge: Cambridge University Press. 
Rifkin, J. (1998/1999). The biotech century. How genetic commerce will change the world. London: Phoenix.

Romein, J. (1956). De eeuw van Azië. Opkomst, ontwikkeling en overwinning van het modern-Aziatisch nationalisme. Leiden: Brill.

Romein, J., \& Romein-Verschoor, A. (1954). Aera van Europa. Leiden: Brill.

Schrödinger, E. (1944/1967). What is life? The physical aspect of the living cell. Cambridge: Cambridge University Press.

Segerdahl, P. (2007). Can natural behaviour be cultivated? The farm as local human/animal culture. Journal of Agricultural and Environmental Ethics, 20, 167-193.

Spengler, O. (1918/1923). Der Untergang des Abendlandes. Umrisse einer Morphologie der Weltgeschichte. Erster Band: Gestalt und Wirklichkeit. München: Beck.

Störig, H. (1961). Kleine Weltgeschichte der Philosophie. Stuttgart: Kohlhammer.

Tolstoy, N. (1878/1984). Anna Karenin. Harmondsworth: Penguin.

Verhoog, H. (2003). Naturalness and the genetic modification of animals. Trends in Biotechnology, 21, 294-297.

Watson, J., \& Crick, F. (1953). A structure for deoxyribose nucleic acid. Nature, 171, 737-738.

Wolpert, L. (1993). The Unnatural Nature of Science. London: Faber \& Faber.

Zwart, H. (1994). The resurgence of nature-speak. Health Care Analysis, 2(3), 221-226.

Zwart, H. (1998). Can nature serve as a criterium for the use of reproductive technologies? In E. Hildt \& D. Mieth (Eds.), In vitro fertilisation in the 1990s: Towards a medical, social and ethical evaluation (pp. 349-360). Aldershot: Ashgate.

Zwart, H. (2000). A short history of food ethics. Journal of Agricultural and Environmental Ethics, 12, $113-126$.

Zwart, H. (2005). Food consumption in the genomics era: A foucauldian perspective. Tailoring biotechnologies, 1(2), 31-44.

Zwart, H. (2007). Slankheid als beschavingsoffensief: de culturele en maatschappelijke betekenis van obesitas. In H. Dagevos \& G. Munnichs (Eds.), De obesogene samenleving. Maatschappelijke perspectieven op overgewicht (pp. 43-52). Amsterdam: Amsterdam University Press. 